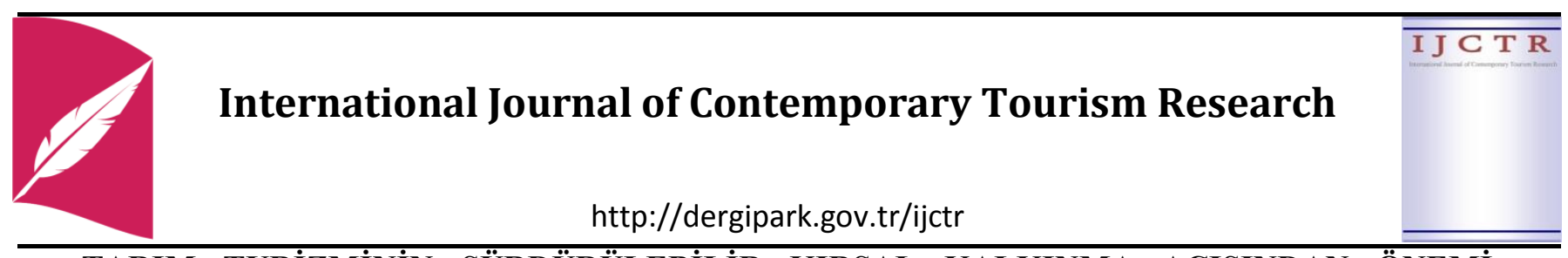

TARIM TURIZMININ SÜRDÜRÜLEBILİR KIRSAL KALKINMA AÇISINDAN ÖNEMİ: BODRUM MANDALINA BAHÇELERİ ÖRNEĞİ

Araştırma Makalesi

\author{
Muharrem TUNA ${ }^{1}$, Şaban KARGIGLIOĞLU² ${ }^{2}$, Demet AĞAOĞLU
}

\title{
ÖZET
}

Türkiye bulunduğu coğrafya itibarı ile verimli tarım topraklara, zengin kültürel mirasa, farklı örf ve adetlere sahip olması sayesinde tarım turizminden faydalanarak sürdürülebilir kırsal kalkınma hedefine ulaşabilir bir ülke olarak göze çarpmaktadır. Çalışma alanı olarak, gerek günümüzde önde gelen turizm merkezlerinden biri olması dolayısıyla gerekse geçmişte balıkçılık, süngercilik, sebze yetiştiriciliği, narenciye yetiştiriciliği ve hayvancılığın geçim kaynakları olması sebebiyle tarım turizmini kapsayan turizm faaliyetlerinin on iki aya yayılmasının hedeflendiği Muğla ilinin Bodrum ilçesi seçilmiştir. Araştırma yöntemi olarak yarı yapılandırılmış mülakat soruları kullanılmıştır. Sorular, sivil toplum kuruluşu çalışanlarına ve gönüllülere sorulmuştur. Çalışmanın amacı, Bodrum'da faaliyet gösteren sivil toplum örgütlerinin Bodrum mandalinasının tarım turizmi potansiyeline yönelik görüşlerini almak ve sürdürülebilir kırsal kalkınma açısından değerlendirmektir. Sonuçlar, Bodrum mandalinasının katma değeri arttıkça üretimden vazgeçme oranında düşüş yaşanacağını göstermektedir. Coğrafi işaret tescili bulunan Bodrum mandalinası ile ilgili yapılan bilimsel çalışmaların artması gerekmektedir.

Anahtar Kelimeler: Kırsal kalkınma, Tarım turizmi, Bodrum, Sürdürülebilir turizm.

JEL Kodları: R51, O13, Q56

\section{THE IMPORTANCE OF AGRICULTURAL TOURISM IN TERMS OF SUSTAINABLE RURAL DEVELOPMENT: THE CASE OF BODRUM MANDARIN GARDENS}

Research Article

\begin{abstract}
Turkey stands out as a country that can reach the goal of sustainable rural development, benefiting from agricultural tourism due to fertile lands found in its geography, rich cultural heritage, and having different customs and manners. As one of leading touristic destinations, Bodrum county, a part of Muğla province, where fishing, sponge hunting, farming, citrus growing and stockbreeding have been main sources of livelihood and where touristic activities ara distributed over the course of the year, has been chosen as a field of study. As a research method, semi-structured

\footnotetext{
${ }^{1}$ Prof. Dr., Ankara Hacı Bayram Veli Üniversitesi, Turizm Fakültesi, muharremtuna@hotmail.com, orcid.org/0000-0001-55267122

${ }^{2}$ Dr., Sinop Üniversitesi, Gerze Meslek Yüksekokulu, skargiglioglu@gmail.com, orcid.org/0000-0002-8952-7225

${ }^{3}$ Doktora Öğrencisi, Muğla Sitkı Koçman Üniversitesi, Sosyal Bilimler Enstitüsü, dagaoglu.d@gmail.com ， orcid.org/00000003-1225-975X
}

"Bu makale 20-22 Eylül 2018 tarihlerinde Kocaeli'de düzenlenen "Uluslararası Gastronomi Turizmi Araştırmaları Kongresi"nde sunulan ve bildiriler kitabında yer alan bildirinin geliştirilmiş halidir."

“Tuna M., Kargiglioğlu Ş. ve Ağaoğlu D. (2020). Tarım Turizminin Sürdürülebilir Kırsal Kalkınma Açısından Önemi: Bodrum Mandalina Bahçeleri Örneği, International Journal of Contemporary Tourism Research, Vol 4: No: 1, p. 31-47, doi: 10.30625/ijctr.654430" 
interview questions were asked to non-governmental organization employees and volunteers. The aim of the study is to evaluate the potential of agricultural tourism from the Bodrum mandarin in terms of rural development by taking the point of views from NGOs operating in Bodrum. As a result, a decrease in rate of giving up on citrus production is expected, as the added value increases. Also, the number of scientific studies focusing on Bodrum Mandarin, which has a geographical indication tag, should be increased.

Keywords: Rural development, Agro-tourism, Bodrum, Sustainable tourism.

JEL Classification Code: R51, O13, Q56

\section{GÍRİŞ}

Türkiye'yi ziyaret eden turistlerin genel olarak profiline bakıldığında, kitle turizmi yani gezi, eğlence (deniz, kum, güneş) ağırlıklı tatili tercih ettiği görülmektedir. Birleşmiş Milletler Dünya Turizm Örgütü'nün son yayımlanan turizm raporuna göre, 2019 yılında dünyay1 gezen turist sayısı 1.5 milyar kişiyi aşmıştır (UNWTO, 2020). 2019 yılında Türkiye'ye, 51.7 milyon kişi turizm faaliyetlerine katılmak üzere gelmiş ve 34.5 milyar dolar harcama yapmıştır (TÜRSAB, 2020). Türkiye'de turizm, döviz girdisini arttıran, istihdama katkı sağlayan, cari açığı kapatmada kullanılan, uluslararası düzeyde toplumsal ve kültürel iletişim sağlayan bir sektördür. Turizm faaliyetlerine katılan kişilerin yıllar içinde kitle turizminden bireysel turizme yöneldiği gözlemlenmektedir. İlk başta, inanç, spor, sağlı, eğitim ve sonrasında deniz-kum-güneş odaklı turizm hareketliliğine katılan bireylerin daha sonra kültür turizmi ve alternatif turizm türlerini seçtikleri görülmektedir. Son zamanlarda, doğaya ve doğal hayata hasret duyan kişiler için turizm çeşitlerine yenileri eklenmiştir.

Tarım ile turizmin ortak özelliklerde olmaları birbirlerini tamamlar nitelikte olduklarını göstermektedir. $\mathrm{Bu}$ sektörlerin birbirleri ile olan ilişkisi, insanların doğal yaşama duydukları özlem ve kaynakların gün geçtikçe azalması tarım ve turizmi bir paydada toplayan tarım turizminin doğmasına sebep olmuştur. Kaynakları koru, kullan felsefesi ile süregelen tarım turizmi, tarımsal alanlara zarar vermeden gerçekleştirilen bir turizm çeşidini ifade etmektedir (Civelek vd., 2014). Tarım turizmi, çevresel açıdan sürdürülebilir olmasından ziyade sosyo-kültürel açıdan da sürdürülebilirlik sağlamaktadır. Yerel değerleri deneyimlemek amaciyla seyahat eden turistler, seyahat ettikleri bölgelerdeki değerlere sayg1 duyarak uyum sağlamaktadırlar. $\mathrm{Bu}$ durumun, yerel halk açısından da faydalı olduğu düşünülmektedir. Geleneksel olarak yapılamakta olup unutulmaya yüz tutan el sanatlarının, ekmek yapımının, yöresel yemeklerin ve zanaatların yeniden talep edilmesiyle birlikte tekrar yaygınlaşma şansı bulmaktadır.

Artık turistler kendilerinin de aktif olarak içerisinde bulunabileceği, kültürel açıdan bilgi sahibi olabileceği ve üretimde yer alabileceği tarım turizmi gibi alternatif turizm türlerine daha fazla önem vermektedir (Akkaşoğlu vd., 2019). Turizmde tüketici tercihleri değişmesiyle, dünyadaki değişime paralel olarak Muğla'ya gelen turistler de doğal ortamlarda, yörenin kültürel değerlerini inceleyebilecekleri, yaşam biçimini deneyimleyebilecekleri, kırsalda kaliteli zaman geçirebilecekleri ürünleri talep etmeye başlamışlardır. Bu kapsamda Bodrum ilçesi, sahip olduğu mandalina bahçeleriyle avantajlı bir konum elde etmiştir ve yaklaşık on yıldır Bodrum Mandalina Bahçelerinin tarım turizmi kapsamında değerlendirilmesi kamuoyunun gündemini meşgul etmekte olduğu görülmektedir. 2023 Turizm Stratejisinde Antalya, Muğla ve Aydın kıyı kesimlerinde deniz-kum-güneşten oluşan kitle turizmine yönelik tatil turizminin doygunluk noktasinda olmasi nedeniyle, bu alanlarda; turistleri otelden çıkararak ikincil harcamaları artıracak, mevcut tesislerin on iki ay çalışmasını sağlayacak, turizm bölgesi açısından kıyı turizmi yanı sıra marka oluşumuna katkı verecek etkinliklerin özendirilerek planlanacağ 1 ifade edilmektedir (Turizm Stratejisi Raporu 2023 Eylem Plan1, 2007).

Bodrum, Ortaca, Fethiye, Dalaman ve Dalyan ilçelerinde yaygın bir şekilde narenciye tarımı (portakal, limon, mandalina, greyfurt) yapılmaktadır. Bodrum mandalina bahçeleriyle ilgili olarak 22-24 Aralık 2017 tarihli Mandalina Şenlikleri dâhilinde 'Bodrum Mandalinası' bahçelerinin sürdürülebilirliğini sağlamak amaciyla 22 Aralık 2017 tarihinde 'Bodrum Mandalinası Bahçelerinin Sürdürülebilirliği Çalıştayı' ve "Bodrum Mandalinası Bahçelerinde 
Agro-turizm Paneli” gerçekleştirilmiştir. Çalıştay ve panel içeriği ile katılımcılar Muğla Sürdürülebilir Kalkınma Derneği tarafından belirlenmiş, sonuç raporu yine adı geçen dernek tarafından hazırlanmıştır. Muğla Sürdürülebilir Kalkınma Derneği, Bodrum Ziraat Odası, Bodrum Belediyesi işbirliğiyle düzenlenen Çalıştay on üç panel, sekiz oturumda gerçekleşmiştir. Her iki etkinliğin sonucunda Bodrum mandalinasından katma değer yaratacak ürünler geliştirilmedikçe mandalina bahçelerinin sürdürülebilirliğinin sağlanamayacağı, ivedilikle konuyla ilgili projeler üretilmesi gerektiği değerlendirilmiştir.

$\mathrm{Bu}$ araştırmanın amacını, Bodrum'da bulunan mandalina bahçelerinin tarım turizminin sürdürebilir kırsal kalkınma odaklı kullanımına dair sivil toplum kuruluşlarında çalışanların ve gönüllülerin görüşlerinin belirlenmesi oluşturmaktadır. Yüz yüze yapılan görüşmelerde elde edilen veriler, bulgular ve sonuç kısmında değerlendirilmiştir.

\section{KAVRAMSAL ÇERÇEVE}

Çalışmanın bu bölümünde; Tarım turizmi, Türkiye'de ve Dünya'da tarım turizmi uygulamaları, Kırsal kalkınma, Sürdürülebilir kırsal kalkınma ile literatür incelemesine yer verilmiştir.

\section{Tarım Turizmi}

Hodur vd., (2008)' Turistlerin doğa temelli olarak gerçekleştirdikleri turizm faaliyetlerinin, çoğunlukla tarım, çiftlik ve yaban hayatına yönelik olarak gerçekleştirilen faaliyetlerden oluştuğunu belirtmektedirler. Tarım turizmi ve çiftlik turizmi, kırsal gelişim ve gelecek nesiller için oldukça önemli bir katalizör görevi görmektedir. Buradan hareketle tarım turizminin doğal kaynakların zarar görmesini engelleyeceği ve sürdürülebilirliğe katk1 sağlayacağ1 düşünülmektedir (Hodur vd., 2008). Dünyada yaşanan tahribatlar ile birlikte şehirlerde meydana gelen çevre ve hava kirliliği, kalabalık ve gürültü sonucunda turist profili ve turizm talebi değişmiş ve tarım turizmine olan ilgi artmıştır. Tarım turizmine yönelik faaliyetler ziyaretçilerin tarımla ilgili bilgi sahibi olmalarını ve hoş bir vakit geçirmelerini sağlarken, üreticiler yani çiftçiler için ekonomik bir gelir kaynağı oluşturmaktadı (Şekerli, 2018).

Agro-turizm kavramı etimolojik açıdan incelendiğinde tarım ve turizm kelimelerinin birleşiminden meydana geldiği görülmektedir (Sznajder vd., 2009). Agri turizm ya da agroturizm olarak da isimlendirilen tarım turizmi, tarımsal üretimin fazla olduğu yörelerde uygulanan bir turizm çeşididir. Tarım turizminin bu özelliği, üreticilere ek gelir kaynağı yaratmasıdır (Küçükaltan, 2002). Amerikan Çiftlik Federasyonu (American Farm Bureau Federation) tarım turizmini, ekili arazilere veya çiftliklere gelen ziyaretçilere (tarım turisti) kar elde etmek amacıyla hizmet veren ve kaliteli zaman geçirmelerini sağlayan işletmeler olarak ifade etmektedir. Tarım turizmi ile herhangi bir tarım işletmesine eğlenme, eğitim veya işletmedeki faaliyetlerle ilgili olan etkinlikler amaciyla yapilan ziyaretler anlatılmaktadır. $\mathrm{Bu}$ ziyaretler ayrıca işletmenin ekonomik sürdürülebilirliğine de katk1 sağlayabilmektedir (Ryan vd., 2006).

Karakaya (2017)'nın tanımlamasına göre;

"Tarım turizmi, temel olarak küçük çiftlikler olmak üzere, çiftçilere ek gelir sağlamak amacıyla băg, bahçe, tarla, ahır, ă̆ll, kümes vb tarımsal üretim alanları ile küçük ölçekli ve geleneksel gıda işleme tesisleri gibi faaliyet alanların ziyaret etmek, günlük işlerine katılmak, çiftlik evinde gecelemek, gezinmek, eğlenmek, alış veriş yapmak ve bazen de eğitim almak gibi aktivitelerin bir veya birkaçını kapsayan bir turizm şeklidir' (Karakaya, 2017).

Tarım turizminin belirgin özelliklerinden bazıları aşağıdaki gibi sıralanabilir (Dorobantu ve Fieldsend, 2011: 49):

- Konaklama, yiyecek-içecek, rekreasyon ve ulaşım maliyetlerinin oldukça düşük olması,

- Bozulmamış ekosisteme ve sakin bölgelere seyahat etme firsatı tanır,

- Turistler geldikleri yerde ulaşamadıkları organik yiyecek-içecekleri tüketme ve satın alma imkanına kavuşurlar,

- Turistlerin, tarımsal faaliyetleri bizzat deneyimlemelerine imkân tanınır,

- Kırsal kesimdeki insanların sahip oldukları gelenek-görenekleri, el sanatları ve yaşam tarzı konusunda bilgi sahibi olunur,

- Turistlerin ziyaret ettikleri bölgelerde, o bölgeye ait gibi davranmalarına olanak tanınır,

- Doğal hayatın sunmuş olduğu özellikteki faaliyetlere katılma olanağı sağlar, 
- Tarım turizmi gerçekleşirken eş zamanlı olarak çiftçilik faaliyetleri de devam eder,

- Tarım turizmi, tarımın gerçekleştiği sürece devam ettiğinden sezon olarak sikıntı olmamaktadır,

- Sadece tarım sektörünü değil, tarım ve turizmle ilgili olan tüm işkollarındaki faaliyetlerde hareketlilik sağlanır.

Türkiye'de tarım turizmi konusunda en önemli örgütlenme Buğday Derneği'nin Tatuta (TarımTurizm-Takas) "Ekolojik Çiftliklerde Tarım Turizmi ve Gönüllü Bilgi, Tecrübe Takası" projesi sonucunda geliştirilmiştir. Proje Birleşmiş Milletler Kalkınma Programı (UNDP), Küresel Çevre Fonu (GEF), Küçük Destek Programı (SGP) ve diğer bazı yerel sponsorlar tarafından fonlanmıştır. Projenin asli amacını Türkiye'deki ekolojik tarım yaparak hayatlarını sürdüren çiftçi ailelerine ekonomik, gönüllü işgücü, ve bilgi desteği sağlayarak ekolojik tarımı teşvik etmek ve onu sürdürülebilir kılmayı hedeflemektedir. Projede, ekolojik üretimin teknik, pazarlama, sosyal, çevresel vs. boyutlarında bilgi/ilgi sahibi kişilerin, çiftlik ve işletmelerde bilgi, deneyim ve/veya işgüçlerini paylaşırken yiyecek, içecek ve barınma ihtiyaçları çiftlik tarafından karşılanmaktadır. Projeye destek veren gönüllüler hem sosyal bir kaynaşmaya hem de yereldeki gerçek tecrübeye ve bu tecrübeye dayalı bilgiye ulaşmaktadır. Proje ECEAT (European Center for Eco-AgroTourism / Avrupa Ekolojik Tarım Turizmi Merkezi) ve WWOOF (Willing Workers on Organic Farms / Ekolojik Çiftliklerde Gönüllü İşçiler) örgütleriyle işbirliği yapılarak yurtdış1 tanıtım desteği sağlanmaktadır.

Proje kapsamında, tarım turizmi yapan, kendilerini ekolojik tarıma adamış çiftçilere, ekolojik üretime devam etmeleri adına ek maddi destek verilmektedir. Turistlerin konaklamalarını, çiftçi ailelerin evinde yapması ve ailelerin turistlerle sofralarını paylaşması, kültürler arası alışverişi sağlamanın yanında, tüketici-üretici arasındaki ilişkilerin şeffaflaşması ile bireylerin ekolojik döngülere ve birbirlerine karşı sorumluluk bilincinin gelişmesine de destek olunmaktadır. Organizasyonda Ekim 2018 itibarı ile yaklaşı 100 tesis bulunmaktadir (www.tatuta.org) Organizasyona bağlı kuruluşların Türkiye'deki dağılımı aşağıdaki haritadan incelenebilir.

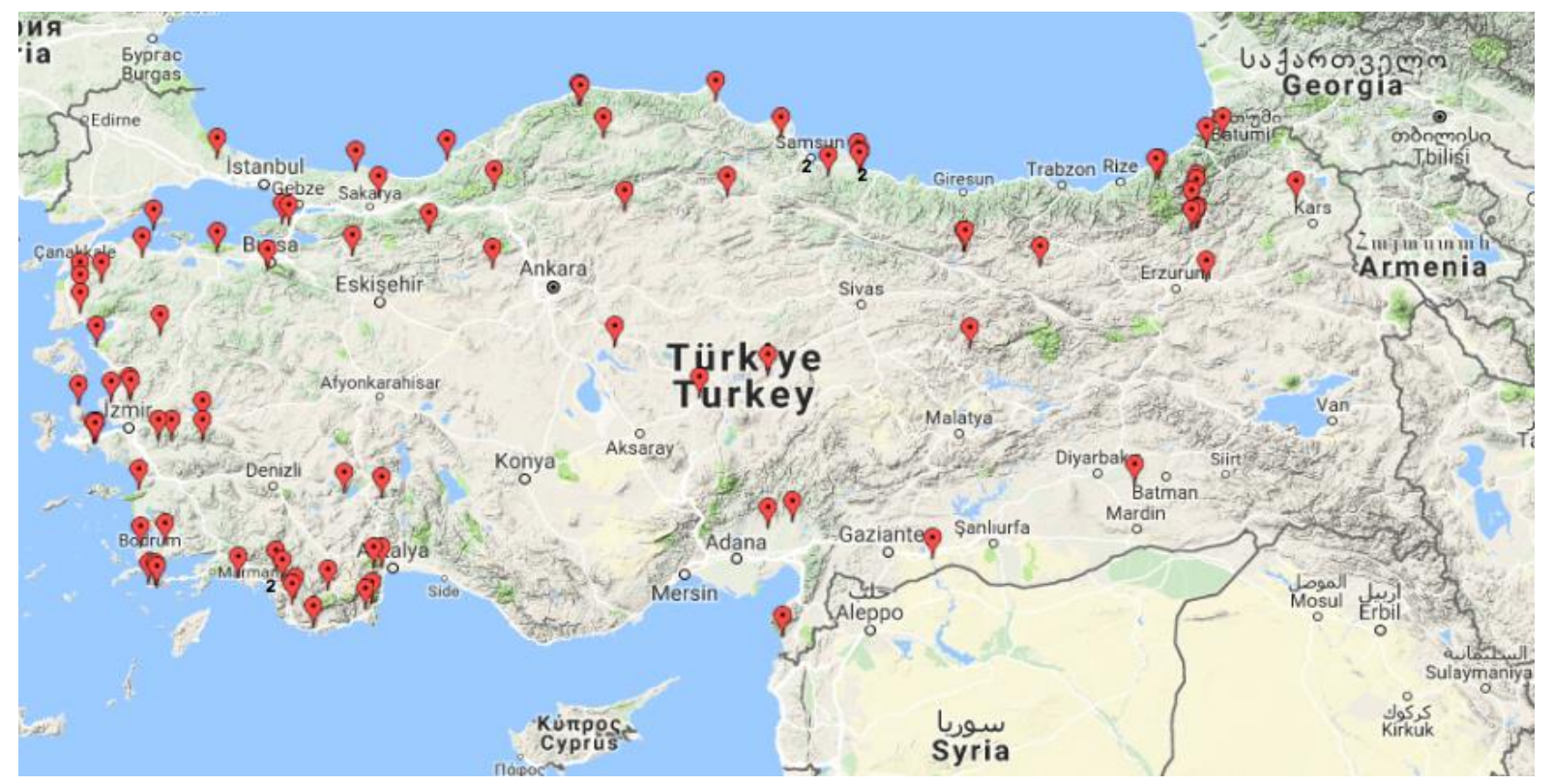

Şekil 1. Tatuta Çiftliklerinin Türkiyedeki Dağılımı

Kaynak: TaTuTa, http://www.tatuta.org/?p=0\&lang=tr.

Türkiye'de Tarım turizmi yapan işletmelerin sayısı turizmde yaşanan tüketici tercihlerindeki değişikliklere paralel olarak artmaktadır. Doğayla dost, çevreye karşı sorumlu, daha azla yetinmeyi bilen, gösterişten hoşlanmayan, doğal yaşamı seven, farklı kültür ve coğrafyayı tanımaya ve 
deneyimlemeye hevesli, stresten uzak tatil geçirmek isteyen turistlere hizmet veren bazı işletmeler aşağıda sunulmuştur:

- Pastoral Vadi Organik Tarım ve Ekolojik Yaşam Çiftliği organik tarım, ekolojik yaşam ve tatil olgularının birlikte değerlendirildiği, ekolojik mimari yaklaşımıyla tasarlanmış taş, ahşap ve kerpiç evlerde y1lın on iki ayı konaklama olanağı sağlamaktadır. Pastoral Vadi'yi ziyaret eden turistlere, çiftlikte organik olarak üretilen veya "Organik Tarım Üreticileri Birliği" üyelerinin bahçe ve tarlalarından toplanan ürünlerden, yöresel geleneksel yöntemlerle hazırlanan yemekler sunulmaktadır (Kılıç ve Kurnaz, 2010).

- Latif Yalçıner Çiftliği, Kemaliye ile Apçağa Köyü arasında yer almaktadır. Meyve bahçelerinin de bulunduğu üç evde yirmi iki kişi ağırlanabilmektedir. Mart-Kasım ayları arasında yaklaşı yüz farklı bitki toplanıp kurutularak "zetrin" adındaki baharat yapılmaktadır.

- Gağgı Çiftliği, İzmir'in Bayındır ilçesinde Sarıyurt köyünde bulunan Karlık dağında 850 metre rakımda 2010 yılında ortaklaşılarak 50 dönümlük bir arazide kurulmuştur. Çiftlikte, farklı dil, din ve 1rktan insanların birlikte bir yaşam sürdürdüğü görülmektedir. Yüzlerce yıllık anıt özelliğe sahip ağaçlar ile çevrili Gağgı Çiftliği'nde, teknoloji ve paranın sadece ihtiyaç halinde kullanılarak yaşam idame ettirilmeye çalışılmaktadır. Çiftlikte yetiştirilen ürünler, gelen ziyaretçiler ile paylaşıldığı gibi kalan ürünlerin kurutularak kış için saklandığ belirtilmektedir.

- Marmariç Ekolojik Çiftliği, örnek sürdürülebilir bir yerleşim yeri olarak, Ege Bölgesi'nde İzmir'in Bayındır ilçesinin Dernekli köyüne bağlı Mersinli mevkiinde kurulmuştur. Çiftlikte, sivil toplum kuruluşlarında çalışmış ve mimar olan ev sahipleri, kiraz, elma, üzüm, zeytin, sebze, ceviz, badem, meyve çeşitlerini yetiştirmektedir. Yetiştirdikleri ürünlerden, pekmez, zeytinyağı ve sabun yapmaktadırlar. Ayrca çiftlikte, alternatif enerji türleri ve ekolojik tarım yöntemleri uygulanmaktadır.

- Balabanağa Çiftliği, Kastamonu'nun Daday ilçesinde yaklaşık 400 dekar tarım arazisi üzerinde bulunmaktadır. Çiftlikte Kastamonu'ya has antik siyez buğdayı, elma, armut, erik, ahlat, alıç, ayva vb. gibi birçok ağaçtan yararlanılmakta ve Karadeniz ikliminde yetişen birçok sebze yetiştirilmektedir. Çiftlikte büyükbaş hayvanlar ve kümes hayvanları bulunmakta olup yoğurt, süt, peynir ve yumurta çiftlik hayvanlarından sağlanmaktadır. Balabanağa Konağı 1636 yılında yapılmıştır. Her biri 400 yıldan daha eskiye dayandığı bilinen çeşme, tarihi Türk hamamı, tahıl ambarı gibi ek üniteleri ile birlikte günümüze çevre ve doğal etkilerden en az zararı görerek gelmiştir. Balabanağa Çiftliği'nde Anadolu'nun geleneksel misafir ağırlama adetleri sürmektedir.

- Narköy, İstanbul'a 90 dakika mesafede Karadeniz kıyısında eğitim merkezi ve organik tarım çiftliği olarak kurulmuştur. Hayvanlar, insanlar ve bitkiler olarak doğal döngü devam ettirilmeye çalışılmaktadır. Narköy'de ayrıca, Nar Eğitim ve Danışmanlık Merkezi'nin ekolojik eğitim merkezi ve oteli de mevcuttur.

- Sevgi Ana Çiftliği, ormana yakın bir arazide, mütevazi bir bahçede üretilen sebzelerin tüketildiği, meyve ağaçlarının bulunduğu, ağaçların araları ile diğer boş alanlar hayvanların yiyeceği otlar ekili, az da olsa kara kovan arıcılık yapılan, ekmek, peynir, yoğurt üretilen, "Doğal Yaşam Atölyesi"leri yapılan, çiftliğe gelen gönüllülerin kalabileceği ayrı bir oda da iki tek kişilik yatak, bahçede banyo, tuvalet, mutfak bulunduğu, ortak yemek yenilebilen, misafirlerin dilerlerse kendi yemeklerini yapabilecekleri bir tesistir.

- Şatıroğlu Konakları, Rize Fındıklı Çağlayan köyünde kütük evi, ahşap evin ve tarihi konağın turizme kazandırıldığı, banyo tuvaleti içerisinde kütük evi, müstakil ahşap evi ve iki oda bir mutfak, banyo tuvaleti olan bir apart ile toplamda grup özelliğine göre 18 ile 28 kişi kapasiteye sahiptir. Karadeniz'in doğal güzelliklerinin, sisli, karlı yaylalarının gezilebilir, yöredeki tarımsal kültürel, folklorik geleneklerin deneyimlenebilir.

- Süleyman Orhan Çiftliğii, İç Anadolu'nun keşfedilmemiş tesislerindendir. Etraftaki meşe ormanında keklik ve tavşanları, köyün yanıbaşındaki gölde ise flamingo, angut, turna ve ördekleri gözlemlemek mümkündür. Gölün şifalı olduğu, çamur banyosunun özellikle romatizmal hastalıklara iyi geldiği 
söylenmektedir. Ayrıca konuklara bölgeye has endemik bir bitki olan ve böbrek taşlarına faydası olan Gilaboru bitkisinin şifalı suyu ikram edilmektedir.

Tarım turizminin, kırsal alanlarda gerçekleşmesi ve doğa tabanlı bir turizm türü olması nedeniyle turistler açısından çekicilik arz etmektedir. Günümüzde kırsal alanların doğallığını ve özgünlüğ̈̈ü tercih eden turist sayısının artmasıyla birlikte kırsal alanların kalkınması hızlanmaktadır (Ongun, Gövdere ve Çiçek, 2016: 80). Planlı ve projeli çalışmalara ihtiyaç duyulan tarım turizmi giderek yaygınlaşmaktadır. (Ak, 2006; Türkben vd., 2012). Türkiye'nin Dünya coğrafyasında birçok ülkeye göre kültürel ve doğal kaynaklarının daha zengin olmasına rağmen, tarım turizminden yeterince faydalanamadığı gözlemlenmektedir (Türkben vd., 2012). Dünya'da tarım turizmi uygulamlarına bakıldığında; İtalya'da tarım turizmi, İsviçre'de samanların içinde uyuma, Yeni Zelanda'da çiftliklerde konaklama, İngiltere'de çiftlik tatilleri, Avrupa ve daha birçok ülke de ise agro-turizm olarak bilinen turizm türü çiftçilerin stratejik olarak önem verdiği alternatif bir turizm türüdür. Ülkelerin stratejik ve coğrafik konumu gereğince tarım turizmi uygulamaları, tarım turizmine verilen önem ve öncelik farklılık gösterebilmektedir (Rilla'dan aktaran Civelek, 2013). Aşağıda bazı ülkelerde yapılan tarım turizmi uygulamalarına değinilmektedir:

- Avustralya'da, tarım turizmi uygulamalarının 1970'li yılların sonlarına dayandığı ve bu ülkede tarım turizminden yararlananlara yönelik fazlaca ürün ve hizmet çeşitliliği sunulmakta olduğu gözlemlenmektedir. Avusturalya'da tarım turizmi, gelen turistlerin en çok tercih ettiği turizm çeşidi olarak göze çarpmaktadır. 1300'e yakın tatil çiftliğinde, uluslararası özelliğe sahip 40'1 aşkın çiftlikte, aynı anda 20 kişiden 200 kişiye kadar grupları barındırabilmektedir. Avustralya'daki tarım turizmi deneyimlerini çiftlik tatilleri, at biniciliği, günlük çiftlik ziyaretleri, şarap tadımı ve bireysel ya da grup turları gibi faaliyetler oluşturmaktadır (Williams vd., 2001).

- İtalya'ya tarım turizmi açısından bakıldığından ilk olarak, sanayileşme ile bilinen kuzey İtalya ile kırsal faaliyetlere dayalı güney İtalya'daki farklılıklar göze çarpmaktadır. 1960'lu yıllardan itibaren ülkede çok sayıda insan tarım topraklarını terk ederek şehirlere göç etmiştir. Tarım topraklarının terk edilmesi sürecinde tarımsal turizm fikri ortaya atılmış, Ulusal Tarım ve Turizm Derneği kurularak tarımla uğraşanların evlerinin odalarını kiraya vermeleri, yerel ürünlerini ticarileştirmeleri gibi amaçlar benimsenmiştir. Sonraki yıllarda tarım turizmine yönelik sunulan ürün ve hizmetlerde artış olduğu görülmekle birlikte kırsal kesimde yaşayan insanların topraklarını terk etmek yerine tarım turizmi uygulamalarına katıldığ 1 görülmüştür (Soykan, 2000).

- Hindistan'daki tarım turizmi uygulamalarında ise, 2008 ve 2010 yılları arasında çeşitli ödüller alındığı gözlemlenmektedir. Hindistan Tarım Turizmi Kalkınma Kurumu'nun ana amacı aşağıda belirtilmiştir:

- Danışmanlık hizmeti vermek,

- Satış ve pazarlama faaliyetlerinde yardımcı olmak,

○ Hindistan'ın kültürünün tanıtılmasın rol oynamak,

- Bölge halkına tarım ve turizmle ilgili eğitimler vermek,

- Rekreasyon, kavramıyla tanıştırmak, eğlence imkânlarını sağlamak. (Agritourism, 2011).

- Polonya'da kırsal alandaki işsizliğin yüksek düzeyde olması nedeniyle tarım turizmi ekonomik dönüşümlerle 1990'lardan itibaren gelişim göstermeye başlamıştır. Günümüzde ise Polonya tarım turizmi faaliyetleri için Avrupa fonlarından yardım almaktadır (Kosmaczewska, 2008: 142). Ülkede, 2000'li yıllarda 5000'nin üzerinde tarım turizmine yönelik çiftlik bulunmakta ve 300.000 'den fazla turistin tarım turizminden yararlandığ görülmektedir.

- Yunanistan'da tarım turizmi konusunda önemli mesafeler kat etmiştir ve hâlihazırda başarıyla işletilen 100 'ü aşkın tarım turizmi tesisine sahiptir. Tarım turizminin gelişiminde devletin mali desteği etkili olmuştur. Ülkenin farklı bölgelerinde birçok kadın kooperatifi tarım turizmi konusunda çalışmalar yapmakta ve pansiyon işletmektedir. Bunların başlıcaları; Thessaly, Viotia, Chios, Lesvos, Thrace, Prespes Gölü tarım turizmi kadın kooperatifleridir (Şen, 2005). 
Tarım turizminin yerel halka ve ziyaretçilere sağladığı pekçok fayda vardır. Önceliklei olarak yerel halka iş olanağı sunması, tarım turizminin göze çarpman faydalarındandır. Özellikle, atıl durumda olan kadın işgücünün ön plana çıkarılması hedeflenmekte ve bu sayede ekonomiye katk1 sunulması beklenmektedir. Bu sayede bölgedeki işsizlik oranının düşürülmesi hedeflenmektedir. Tarım turizmi, alternatif ya da sürdürülebilir geleneksel bitkisel ve hayvansal üretimin varlığını, tarımın katma değer yaratması, doğrudan çiftlik ürünlerinin pazarlanmasına olanak tanıması, özellikle kırsal alandaki yerel halkın kalkınmasını sağlamada önemli bir rol üstlenmektedir (Karakaya, 2017).

\section{Sürdürülebilir Kırsal Kalkınma ve Tarım Turizmi İlişkisi}

Kalkınmada esas amaç toplumun refah seviyesini yükseltmektir. Bunu sağlamak için Gayri Safi Milli Hasıla artırılmalıdır. Üretimi etkileyen sosyal, kültürel ve ekonomik gelişimin sağlanması için gereken finansmanın kaynağını milli gelir olușturmaktadır. Yapılacak üretim artıșının tüm toplumun refah seviyesinde aynı düzeyde iyileşme sağlayabilmesi için üretimin bütün ekonomik faaliyet alanlarında marjinal verimlilik düzeyinin aynı olması gerekir. Tüketim mallarına ve hizmetlere erişimde marjinal faydanın bütün bireylere eşit derecede olması refah seviyesini yükseltmek ve sosyal adaleti sağlamak için önemlidir (Turan, 1975: 161-163).

İlk defa 1987 yılında Dünya Çevre ve Kalkınma Komisyonu tarafindan hazırlanan Ortak Geleceğimiz Raporunda yer alan sürdürülebilir kalkınma kavramı; gelecek kuşakların en azından bugünkü nesle benzer tüketimlerini karş1lamalarından ödün vermeden, bugünkü kuşaklar için tüketim olanakları yaratmak ya da gelecek kuşakların kendi ihtiyaçlarını karşılama hakkını tehlikeye atmaksızın, bugünkü kuşakların ihtiyaçlarını karşılamaya çalışmak şeklinde tanımlanabilir (Geray, 1998). Sürdürülebilir kalkınma, mevcut doğal kaynakların bugünkü kullanımını, gelecek nesillerin kullanımını da sağlamaya yönelik olarak en uygun düzeyde gerçekleştirerek, ülkelerin kalkınmasının önünü açmaya olanak sağlamaktadır (Üzümcü vd., 2019). Her ülke sürdürülebilir kalkınmayı sağlamak için kendi doğal kaynaklarını, iktisadi ve sosyal yapısını planlamaya ve koruma-kullanma dengesi içinde yönetmeye çalışmaktadır. Türkiye'de de kalkınmayı bir plan bağlamak için 1963 yılından beri planlı kalkınma dönemine geçilmiş ve son yıllarda yapılan kalkınma planlarında "hızl, dengeli ve sürdürülebilir kalkınma" anlayışı esas alınmıştır (Daşdemir veYılmaz, 2016).

Kırsal alanda yaşayan halk genellikle tarım, hayvancılık, balıkçılık gibi katma değeri düşük ekonomik faaliyetlerle geçimini sağlamaya çalışmaktadır. Genellikle kırsal kalkınma ile tarım politikaları birbirinin yerine kullanılan terimlerdir. Kırsal kalkınma politikaları ekonomik faaliyetlerin yanı sıra sosyo-kültürel faaliyetleri de içeren kapsamlı bir kavramdır. Kırsal nüfusu yerinde kalkındırmak, kentsel yaşam ve kırsal yaşam arasındaki sosyal, kültürel ve ekonomik farklılıkları bir dengeye ulaştırmak için politikalar oluşturmak kırsal kalkınmasının konusudur (Gülçubuk 2002). 'Kırsal kalkınma, tarımsal kalkınmaya ek olarak; kırsal altyapı, tarımsal altyap1, eğitim, sağlık, sosyal güvenlik, örgütlenme, barınma, ulaşım, iletişim, işlendirme, pazarlama, kırsal turizm, yöresel el sanatları vb. gibi sosyal, kültürel ve ekonomik alanlardaki var olan gereksinimlerin ve önceliklerin belirlenmesi ve belirlenen konularda yetersizliklerin giderilmesi-iyileştirilmesi için planlanan tüm geliştirici etkinlikleri anlatmaktadır' (Kırsal Kalkınma Raporu, 2002). Bu nedenle kırsal kalkınma konusunda uzman kişiler, kırsal alanlarda yaşayanların (özellikle dağlık ve ormanlık bölgelerin) tarım ve ormancilık faaliyetleri dışındaki uygulamalarla desteklenmesi gerektiği konusunda hem fikirdirler. Bunların başında da kırsal sanayi ve kırsal turizm gibi, kırsal alanlarda göç sorununu çözecek, fazla işgücünü değerlendirecek ve ek gelir sağlayacak alternatif faaliyetler gelmektedir (Esengün vd., 2000). İnsanın kırsal alanlarda coğrafi potansiyeli kullanımı, arz ve talebin çeşitlenmesi, kullanımla ilgili yeni alanları keşfi ve değerlendirmeye geçişiyle kırsaldaki faaliyetler daha da gelişmiş, çeşitlenmiştir. Kırsal alanları sadece tarımsal üretime ait yerler olarak görme fikri değişmektedir. Sürekli değişen kimliği ile kırsal alanlar, "kırsal kalkınma" olarak ifade edilen farklı ekonomik faaliyetlerle de öne çıkar hale gelmiştir. $\mathrm{Bu}$ süreçte, yerel potansiyel kaynakların farklı şekilleriyle değerlendirilmesi bölge halkı için önemli bir ekonomik girdi oluşturacaktır (Akova ve Şahin, 2019). Bölge ve toplum açısından birçok 
önemi bulunan tarım turizminin; bölgedeki yerel işletmeler için doğrudan ek gelir imkânı yaratması, bölge halkının tarımla ilgili konularda eğitilmesi, konu ile ilgili farkındalık oluşturması, yöre halkının gelir artışı ve istihdamına katkı sağlaması, çiftçilerin tarıma devam etmesi, yerel tarımsal ürün ve hizmetlerin kullanımını teşvik etmesi gibi faydaları bulunmaktadır (Williams vd.,2001; aktaran Akkaşoğlu vd., 2019).

Kırsal kalkınma, kırsal alanların nüfusun yoğun olarak yaşadığı kentsel alanlara göre ekonomik, kültürel ve sosyal açıdan geri kalmış olması nedeniyle kırsal alanda yaşayan bireylerin yaşam standartlarının yükseltilmesi amaciyla gerçekleştirilen ekonomik, kültürel ve sosyal yap1 dönüşümüdür (Uzunpınar, 2008). Toplumun gelir ve refah seviyesinin yükseltilmesi için kalkınma sürecinde uygulanması gereken politikalara kalkınma stratejisi denir. Genellikle tarım reformu denilen çoğu zaman vergi reformu, birlikler kurma ve kooperatifleşme benzeri politikalarla da desteklenen bu strateji ülkenin siyasi, sosyoekonomik şartlarına göre farklılıklar göstermesine karşın genelde; tarımsal verimliliği artırmayı, tarımsal alanlardaki işgücü fazlasını değerlendirmeyi, endüstri girişimi oluşturmayı ve artırmay1, tarımsal üretim biçiminin endüstriyel yönde evrilmesini sağlamayı hedeflemektedir. Tarımsal kalkınmada hedefler belirlenirken ulusal kalkınma hedefleri ve tarım sektörünün milli gelire yapacağı katk1 göz önünde bulundurulur (Turan, 1975). 1992 yılında, Rio'da toplanan ülkelerin gerçekleştirdikleri "Rio-Gündem 21" isimli uluslararası toplantıda, ülkelerin ulusal kalkınma plan ve hedeflerine uygun politikalara işlerlik kazandırılması kararlaştırılmıştır. $\mathrm{Bu}$ kararlardan birisi de tarım turizminin geliştirilmesidir. $\mathrm{Bu}$ toplantıda alınan karara göre; "kırsal alandaki yoksul nüfusu marjinal toprakları kullanma zorunluluğundan uzaklaştırmak için; kırsal sanayi, dokuma sanayi, balıkçılık ve kırsal turizm gibi tarım dişı istihdam alanlarının oluşturulması" öngörülmüştür (Gündüz, 2004).

Kırsal kesimlerin kalkındırılması amaciyla kullanılacak kırsal turizm dünyanın genelinde kabul görmüş bir uygulamadır. Kırsal turizmden elde edilen önemli başarılar, kırsal yörelerin gelişiminde tarıma ek olarak kırsal turizmin alternatif bir yaklaşım olarak görülmesini sağlamaktadır. Kırsal turizm kırsal bölgelerde tarım dişı çeşitlendirmenin başarı sembolüdür (Soykan, 2006). Ayrıca kırsal alanlardaki doğal ve kültürel varlıkların zenginliği ve çeşitliliği turizm ve rekreasyon faaliyetlerinin geliştirilmesi açısından da düşünüldüğünde kırsal turizm önemli bir potansiyel arz etmektedir (Çeken vd., 2007).

Kırsal bölgelerde yaşanan göçler; kentlerde sosyal ve kültürel içerikli sıkıntılara, kırsal alanlarda ise üretim ve nüfusun azalmasına neden olmaktadir. Teknolojik gelişmelerle birlikte ihtiyaç duyulan doğal kaynakların ve bu kaynaklara erişim sırasında çevreye verilen geri dönüşü olmayan tahribatın sürdürülebilirlik adına olumsuzluk oluşturabileceği gelişmeler olarak görülmektedir. Köyden kente göçü yavaşlatacak, ama bu arada kırsalda yaşayan insanların yaşam standartlarını kentlerde yaşayanlara eşitleyecek kırsal kalkınma programlarının uygulamaya geçirilmesi bir zorunluluk olarak görülmektedir. Turizm faaliyetlerinin kırsal alanların gelişiminde önemli bir yere sahip olduğu bilinen bir gerçektir. $\mathrm{Bu}$ sebepledir ki; kırsal turizmin kırsal kalkınmada kullanılmasının, kırsal alanlarda yaşayanların yaşam standartlarını yükseltecek önemli değişmeler yapacağ1 yönünde genel bir kanı bulunmaktadır (Kuşat, 2014).

\section{Bodrum İlçesi'nde Sürdürülebilir Turizmin, Mandalina Bahçelerinde Tarım Turizmiyle İlişkilendirilmesi}

Dünya Ekonomik Forumu tarafindan yayımlanan, "2017 Uluslararası Seyahat ve Turizm Rekabet Endeksi"ne göre ülkemiz 44. sırada olup yaklaşık 26,6 milyon dolar gelir elde etmektedir. Aynı rapora göre yaklaşık 39,4 milyon ziyaretçinin kişi başına turizm harcaması yaklaşı 674 Amerikan dolarıdır. Bodrum Turizm danışma Bürosu verilerine göre Bodrum'a 2017 yılında gelen turist sayıs1 778.000' dir. Yaklaşık turizm geliri 525.000 Amerikan dolarıdır. Türkiye'de Gastronomi Turizmi Derneği'nin yapmış olduğu "2017 Yı1ı Gastronomi Turistlerine Yönelik Araştırma" sonuçlarına göre, Türkiye'ye gastronomi amaçlı gelen turistlerin harcamalarının yaklaşık \%27'si, normal turistlerin harcamalarının ise yaklaşık \%20'si gastronomik amaçlıdır. Muğla araştırmanın yapıldığı beş ilden biridir. Bu durumda Bodrum'un normal turizm gelirlerinin \%20'sinin gastronomik amaçlı harcanan tutar olduğunu düşünecek olursak, Bodrum'un gastronomi turizminden elde ettiği gelirin yaklaşık 105.000 Amerikan doları olduğunu 
söyleyebiliriz. Bodrum'un yöresel lezzetlerinin yaşatılması bu rakamların artmasına katkıda bulunacağı düşünülmektedir. Muğla İl Tarım ve Orman Müdürü Barış Saylak'ın beyanına göre, 2020 yılında 170 bin mandalina ağacina ulaşıldığııı ifade ederek, Bodrum'un farklı bölgelerinde bulunan 4 bin 500 dekar alandaki mandalina bahçelerinden y1lda 7 bin 200 bin tona yakın toplam ürün elde edildiğini kaydetmiştir. Ayrıca bölgenin kırsal turizmi anlamında tanıtımına katkı sunan festivallerin, ürünün markalaşma sürecini hılandıran bir unsur olduğunu vurgulamıştır (Muğla Gazetesi, 2020).

Yerel değerlerin giderek önemli hale gelmesi, yerel kültüre ait ürünlerin taklitlerinden korunması ve haksız rekabete maruz kalmalarını engellemek amacıyla yasal düzenlemeler yapılmaktadır. Bir ürünün, sınırları belli bir bölge veya alanla anılarak tescillenmesi, coğrafi işaret kavramının ortaya çıkmasına sebep olmuştur (Acar, 2018: 164). Coğrafi işaretler, tüketicileri ürünün bulunduğu bölgeye çekerek, turizmin canlanmasına katk1 da bulunmaktadır. Bölgenin gelişimi için önem arz eden bir unsur olan turizm, yöresel ürünlerin ön plana çıkmasına yardımcı olan bir sektör olarak kabul edilmektedi (Mercan ve Üzülmez, 2014: 68).

İlçeye özgü değerlerin ve yöresel lezzetlerin kaybolmaması için muhtelif sivil toplum örgütleri ciddi gayret göstermektedir. Bodrum'a katma değer sağlayacak, coğrafi işaret ile tescil edilebilecek pek çok ürün bulunmaktadır. Bodrum Mandalinası 2012 y1lında coğrafi işaret tescili yapılmış bir üründür. Kuvvetli bir aromaya sahip olan bu ürün çekirdeğinden ötürü sofralık olarak tercih edilmemektedir. Mandalina üreticilerinin ürünlerinin değerlendirilmesi amacıyla ilçede bulunan Narenciye Üreticileri Birliği'nce mandalina yağ1 üretimine başlanılmıştır. Ürünün sadece suyu ya da yağı değil, kabukları, çekirdekleri ve yapraklarının değerlendirilmesi de gündemdedir. İlçenin turistik ve ikincil konut cazibe merkezi olmasi nedeniyle mandalina bahçeleri imar ve rant baskısı altındadır.

Bodrum Mandalinası'nın zamanda yolculuğu aşağıdaki gibidir: (Ağaoğlu, 2018)

$\checkmark 1671$ - 'Bodrum'da limon, turunç yetişiri"' Evliya Çelebi

$\checkmark 1947$ - Kalimnos’tan Mandalina Fidanlarının Getirilmesi $\checkmark 1964$ - 620.000 Narenciye Ağacı $(543.000$ Mandalina A ğac1)

$\checkmark 1980$ - Mandalina Bahçelerinin İmara Açılmas1

$\checkmark 2012$ - 290.530 Mandalina Ağacı

$\checkmark \quad 2014-180.900$ Mandalina Ağacı

$\checkmark 2017$ - 39.000 Mandalina Ağacı (İlçe Gıda Tarım ve Hayvancılık Müdürlügü Çiftçi Kayıt Sistemi verilerinden alınmıştır)

Zaman içerisinde giderek azalan bu bahçelerin mevcut hali ile korunması ve çoğaltılması amacıyla bahçe sahipleri ve sivil toplum kuruluşları üyeleri kamuoyu oluşturmaya çalışmaktadır. Yöre halkının mandalina bahçelerini korumalarının sağlanması, mandalinanın katma değerli ürüne dönüşmesi ve mandalina bahçelerinin tarım turizmine açılması ile mümkün olabilecektir. Son y1llarda, sivil toplum kuruluşları konuya özel önem vermiş, pek çok festival, çalıştay, panel vb. çalışma yapılmıştır. Bodrum'da tarım ve turizmde bütüncül yönetim sağlandığında, ilçede on iki ay kesintisiz turizm faaliyetinde bulunulabilecektir. Son derece zengin flora, fauna ve bunun paralelinde yöresel lezzete sahip ilçenin gastronomi turizmi açısından çok daha yüksek değerlere ulaşması beklenmektedir.

\section{YÖNTEM}

Bodrum mandalina bahçelerinde tarım turizminin sürdürülebilir kırsal kalkınma açısından öneminin araştırıldığı bu çalışmada, araştırma yöntemi olarak nitel araştırma yöntemi olan görüşme tekniği kullanılmıştır. Araştırmada nitel araştırma yönteminin kullanılmasının temel sebebi; katılımcıların düşüncelerini derinlemesine elde etmektir. Araştırmaya katılmayı kabul eden katılımcılardan yüz yüze görüşme yapılabilmesi için randevu istenmiş ve randevu listesi oluşturulmuştur. Görüşmelerin tamamı, gönüllülük esasına dayalı olarak araştırmacı tarafindan gerçekleştirilmiştir. Yarı yapılandırılmış görüşme formu yardımıyla yüz yüze görüşme yapılarak katılımcının görüşleri alınmıştır. Ana teknik olarak görüşme tekniğinin yanı sıra doküman analizi ve gözlem de araştırmada kullanılan diğer tekniklerdir. $\mathrm{Bu}$ çalışmada olasılıklı olmayan örnekleme yöntemlerinden, amaçlı örnekleme yöntemi çerçevesinde azami çeşitlilik örneklemesine başvurulmuştur.

Bodrum'da faaliyet gösteren sivil toplum kuruluşlarının yönetici, üye ve gönüllülerinden oluşan 22 kişinin 12 konu başlığ 1 hakkında 
görüşleri alınmıştır. Yapılan görüşmeler 1 Aralık 2017-31 Ocak 2018 tarihleri arasinda tamamlanmıştır. Çalışmaya zenginlik kazandırması açısından gerekli durumlarda görüşme formu dışında ilave sorular da sorulmuştur. Katılımcılar Bodrum Mandalinası'nın sürdürülebilirliğinin sağlanması amacıyla mülakatların yapılmasına oldukça katkıda bulunmuşlardır. Görüşmelerin ortalama olarak 50 dakika ile 70 dakika arasında olduğu belirtilmektedir. Görüşmeler ses kaydı alınarak sürdürülmüş ve sonrasında yazılı hale getirilmiş ve kontrolü sağlanarak doğrulanmıştır. Araştırma Aralık 2017-Ocak 2018 tarihleri arasında Bodrum'da faaliyet gösteren sivil toplum kuruluşu yöneticisi, üyesi ve gönüllülerine uygulanmıştır.

\section{BULGULAR}

Çalışmanın ilk bölümünde veri toplanan kişilerin demografik özelliklerini tespit etmek amaciyla cinsiyet, yaş, eğitim durumu, işkolu ve çalışma sürelerini belirlemeye yönelik sorulan soruların yanıtları yorumlanmıştır. Sonraki kısımda katılımcıların, teknik ve sosyal alt yapı, yeşil alan, turistik işletmelerin yeterliliği, ulaşım olanakları, bölgenin tanıtımı için yapılan tanıtım faaliyetlerinin türleri ve yeterliliği, turizm tarım etkileşimi, turistik tesis yapımıyla kaybedilen/kaybedilmekte olan mandalina bahçeleriyle ilgili düşünceleri, Bodrum mandalinasından elde edilen turistik ürünlerin yeterliliği, alternatif ürünler, Bodrum'da yemeiçme tesislerinin menülerinde mandalinalı ürünlerin varlığı, Bodrum mandalina bahçelerinin turizme açılmasının kırsal kalkınmaya etkisi, Bodrum mandalina bahçelerinin turizme açılmasının olumsuz etkileri, tarım turizmi kapsamında Bodrum mandalina bahçelerine yapılacak yatırımlarda çevresel sürdürülebilirlik, yenilenebilir enerji kaynaklarının kullanılması, Bodrum mandalina bahçelerinin sürdürülebilir turizm kapsamında kullanılması konularında hazırlanan sorulara ilişkin görüşlere yer verilmiştir.

Bodrum'da mandalina bahçelerinin tarım turizmine açılması konusunda yapılan yar1 kontrollü mülakata katılanların Katılımcıların yaş ortalaması 53'tür ve bu grubun \%30'u kadın, \%70'i erkektir. Katılımcıların sivil toplum kuruluşlarındaki pozisyonları incelendiğinde \%32'sinin sivil toplum kuruluşlarında yönetici, \%54'ünün üye, \%9'unun çalışan, \%5'inin gönüllü olduğu tespit edilmiştir.
Katılımcıların eğitim düzeyleri incelediğinde, \%5'inin yüksek lisans, \%72'sinin lisans, \%3'ünün ortaöğretim, \%20'sinin ilköğretim okulu mezunu olduğu belirlenmiştir. Katılımcıların yaklaşık \%60'1 tarımla, \% 23'ü turizmle uğraşmaktadır. Tarımla uğraşan katılımcıların genellikle emekliliklerini hak ettikleri öğrenilmiştir. Mülakatlara katılan sivil toplum kuruluşları mensuplarının, \%61'inin 15 y1ldan fazla, \% 9'unun 6-15 y11, \%30'unun ise 5 yıldan az mesleki deneyimi vardır. Mülakatlara katılanların entelektüel seviyelerinin yüksek olduğu gözlenmiştir.

Katılımcıların, Teknik ve Sosyal Alt Yapı, Yeşil Alan ile Turistik İşletmelerin Yeterliliğine İlişkin Görüşleri:

Katılımcıların tamamına yakını kentsel alt yapıya dair ciddi sorunların olduğunu, atıkların bertarafi, kanalizasyon ve arıtma yatırımlarına ihtiyaç duyulduğunu, yeşil alanların yetersiz olduğunu bunlara karşılık konaklama işletmelerinin sayısının yeterli olduğunu ve hatta bölgede yapılan yeni konaklama tesislerinin gereksiz bir yatırım olarak değerlendirilebileceğini, yapılan her tesisin çok ciddi çevre sorunlarını beraberinde getirdiğini dile getirmişlerdir. En önemli sorunun Bodrum Kalesi, Mozole, Antik tiyatro gibi kültürel mirasın yeterince korunamaması ve değerlendirilememesi olarak belirtilmiştir. Ayrıca ilçe içindeki dar sokakların ulaşım ihtiyacını karşılamadığı, zaman içerisinde dere yatakların üzerine asfalt dökülerek yola dönüştürüldüğü ve yağan şiddetli yağmurlarda taşkınların oluştuğundan, ekosistemin dengesinin bozulduğundan yakınılmaktadır.

Katılımce 17'nin 'Kilisenin bakımı bir an önce bitirilmeli. Restorasyon yapilarak turizme kazandırılacak pek çok yap1 var. Arkeolojik yatırımlar son derece az." şeklindeki görüşlerini, Katılımcı 22: "Kent kimliğine dair çalışmalara önem verilmeli. Kentsel tasarım bağlamında yerel yönetimler, sivil toplum kuruluşları ortak çalışmalar yapmalı. Binlerce y1l, çok farklı medeniyetlerin bulunduğu bu coğrafyada kültürel, arkeolojik, zirai değerleri barındıran tasarımlara önem verilmeli." diyerek desteklemiştir.

\section{Katılımcıların, Ulaşım Olanaklarının Yeterliliğine İlişkin Görüşleri:}

Katılımcıların tamamına yakını genel olarak bölgede ulaşım araçlarının ve hatların kapasiteleri konusunda sorun olmadığını belirtmişlerdir. 
Bununla beraber hızlı kentleşme nedeniyle özellikle yaz aylarında trafiğin arttığını ve karayollarının yetersiz geldiğini dile getirmişlerdir. Katılımcıların yaklaşık \%30’u doğa dostu ulaşım araçlarının desteklenmesini, ilave çevre yolu yapımının doğal katliama yol açacağını, karada bisiklet yollarının, denizde toplu taşımanın yapılabileceği hatların açılmasını önermişlerdir.

Katılımcı 16: "Yazın ulaşımın trafik nedeniyle, kışın sefer sayılarının azlığının zaman kaybına yol açıyor".

Katılımce 15: "Yillardır transfer hizmetinde bulunduklarını, yakıt fiyatlarındaki artışın ister istemez turiste yansıyor, deniz ulaşımına önem verilmeli" şeklinde görüş belirtmiştir.

Katılımcıların Bölgenin Tanıtımı İçin Yapılan Tanıtım Faaliyetlerinin Türleri ve Yeterliliği Hakkında Görüşleri:

Katılımcıların tamamı bölgenin tanıtımı için yapılan faaliyetlerin yetersiz olduğunu, yöreye dair turistik ürünlerin daha fazla olması gerektiğini ve mevcudun tanıtımının yeterince yapılamadığını belirtmişlerdir. Katılımcıların tamamına yakını bölgede turizmin gelişmesi ve tanıtımı için gerekli finansmanın yetersiz olduğunu düşünmektedir. Katılımcıların \%50'sine yakını bölgenin sadece eğlence amaçlı turizme değil, kültürel değerlerinin ön plana çıkarıldığ 1 turizm faaliyetlerinin geliştirilmesinin gerektiğini, bunun için somut ve somut olmayan kültürel mirasın tanıtımına dair alt yap1 düzenlemelerinin yapılmasına öncelik verilmesini önermişlerdir. Ayrıca yörenin kongre turizmi kapsamında tanıtımının için uluslararası organizasyonlar ve üniversiteler ile diyaloğun güçlendirilmesi gerektiği vurgulanmıştır.

Katılımcı 14: "Turizm fuarları yeterli değil, biz kültürel değerlerimizi kaybediyoruz. Guletlerimiz vard1, sandaletimiz. Usta kalmadı. Deniz-kumgüneş nereye kadar? Bahçeler de hep satıldı. Gençler geçmişe sahip çıkmıyor. Bir tek dügünlerimiz kaldı. Turist niye gelsin?"

Katılımcı 11: "Bodrum'da pek çok etkinlik var ancak bunlar zamanında duyurulmuyor. Katılım düşük oluyor. Fuarlar önemli ama asıl olan yerel etkinlikler, kışın oteller boş, kongre turizmi, akademik etkinlikler düzenlenebilir." şeklinde görüş bildirmişlerdir.

\section{Turizm Tarım Etkileşimi:}

Kat1lımciların \%80'i Bodrum'da turizm gelişmeden önce halkın tarımla geçindiğini, gerek tarımsal arazilerde arpa, buğday gibi tarla bitkilerinin, üzüm, narenciye yetiştiriciliğinin yapıldığını, gerekse denizlerden balıkçılık ve sünger avcılığının yaygın olduğunu, kendilerinin ailelerinin tarımsal faaliyetlerinden elde ettikleri gelirle yetiştiğini belirtmişlerdir. Zamanla halkın tarımdan uzaklaştığını ve turizm sezonundan elde edilen gelirle bir yıl boyunca yaşam döngüsünün sağlanmasının cazibesine kapıldığından yakınmışlardır.

Katılımcıların tamamına yakını Bodrum'da turizmde kalite sorununun giderek arttığını, yüksek gelir grubundaki turistlerin mülk satın alımı yoluna gittiklerini, düşük gelirli turistlerin ise harcamalarının beklenen düzeyde olmadığını, aşırı yapılaşmanın doğal güzelliklerin tahrip olmasına yol açtığını savunmuşlardır. Katılımcıların tamamı narenciye bahçelerini kentsel peyzaj objesi olarak görmek istemediklerini, özellikle 'Bodrum Mandalinası' bahçelerinin korunması gerektiğini, tarımla bütünleşik turizmin alternatif ve özlenen bir turizm biçimi olduğunu vurgulamışlardır. Tarım ve turizmin bütüncül bir şekilde yönetilmesinin ilçeye katma değer sağlayacağını dile getirmişlerdir. Doğaya dost turistlerin ilçeye gelmesinin, yöresel değerlerin korunmasında ve önemli katkılarının olacağını, tarımsal alanların korunmasının sürdürülebilir turizm için şart olduğunu, gelecek kuşaklar için zorunluluk olduğunu savunmuşlardır.

Katılımce 9: "Hem tarım hem turizmle ilgileniyorum. Otelim var, bahçemde, tarlada ürettiklerimi mutfakta kullanıyoruz ama yetmiyor. Denizde balık kalmadı. Çocuklarım işime ne kadar sahip çıkar bilemiyorum."

Katılımcı 21: "Y1llardır köyümde bunun mücadelesini veriyorum. Kendi çocuğum bile tarladan, bahçeden koptu. Marinada çalışıyor. Tarım alanları yok edilmemeli, tarımdan elde ettiğimiz gelir yetmiyor. Kira gelirleri olmazsa zorlanıyoruz." şeklinde görüş bildirmişler ve geleceğe dair kaygılarını ön plana çıkarmışlardır.

\section{Turistik Tesis Yapımıyla Kaybedilen, Kaybedilmekte Olan Mandalina Bahçeleriyle İlgili Düşünceler:}

Katılımciların tamamina yakını son yıllarda turistik tesislerden ziyade tarım alanlarının imara açılması 
nedeniyle mandalina bahçelerinin sökülmeye başlandığını, mandalina ağaçlarının aksesuar görevi görmeye başladığını dile getirmişlerdir. Katılımcıların tamamı mandalina bahçelerinin korunması gerektiğini belirtmişlerdir. Zorunlu nedenlerle sökülen mandalina ağaçlarının uygun yerlere nakil edilmesi gerektiği, yeni fidanların yetiştirilmesi gerektiği ve bu konuda yapılacak çalışmalara destek olmak istediklerini ifade etmişlerdir. $\mathrm{Bu}$ konuda bazı katılımcıların düşünceleri şu şekildedir:

Katılımeı 2: "Verimli tarım alanları ve mandalina bahçeleri turistik tesislere dönüştürülmemeli ve kültürel mirasımıza sahip çıkmalıyız."

Katılımcı 7: "Tek kelime ile kıyım! Geç kalındı." Katılımcı 8: "Kaybedileni geri getiremeyiz. Kalan narenciye ve diğer ağaç varlıklarımızın korunması, turizme entegrasyonu ile mümkündür."

\section{Bodrum Mandalinasından Elde Edilen Turistik Ürünlerin Yeterliliği, Alternatif Ürünler:}

Bodrum Narenciye Üreticileri Birliği, mandalina konsantresi ve yapı üretiminde bulunmaktadır. Mandalina konsantresi özellikle mandalinalı gazoz ve soda üretiminde kullanılmaktadır. Narenciye yağının ve narenciye yağı kullanılan ürünlerin pazar payının artırılması konusunda çalışmalar devam etmektedir. Narenciye üreticilerinin elde ettikleri gelirin üretim maliyetlerini karşılamaması ve Birlik tarafindan teklif edilen birim fiyatı yeterli bulmamaları nedeniyle narenciye üretiminde yapılmas1 gereken tarımsal faaliyetleri (budama, sulama, zararlı mücadelesi vb.) yapmadikları gözlemlenmektedir. Bununla birlikte Bodrum mandalinasinın suyunun, konsantresinin veya yağının gazoz, lokum, çikolata, bisküvi, reçel, dondurma, kolonya, oda kokusu, krem, sabun, mum yapımında kullanıldığ 1 belirlenmiştir. Katılımciların sadece \%5'i mandalinalı oda kokusu ve krem yapıldığının farkında olmadıklarını ifade etmişlerdir. Ancak üretilen ürünlerin olabildiğince organik olmasının bilinçli tüketicilerce tercih edilmesini artıracağını ve dolayısıyla mandalinadan daha yüksek kazanç sağlanacağını belirtmişlerdir. Ayrıca mandalinalı tatlı çeşitlerinin sayısının artabileceği vurgulanmıştır.

Katılımcı 6: "Özellikle İtalya, İspanya gibi narenciye üretiminde söz sahibi ülkelerde yapılan araştırmaların incelenmesi gerekir."

Katılımcı 13: "Narenciye Birliği çok düşük fiyattan alıyor, bahçe masrafı çıkmıyor. $\mathrm{Bu}$ şekilde işleyecek ürün bulamazlar. Esasen mandalina aromasını yöresel lezzetlere katmalı"

Katılımcı 16: "Endüstriyel ürünler üretmeye çalışıyoruz. Bugüne kadar pek çok ürün geliştirmeye çalıştık, ancak finansman olarak zorlandık, ürün çeşitliliğini artırmayı hedefliyoruz, ancak pazarlamada zorlanıyoruz." ş̧eklinde görüş bildirmiştir.

\section{Bodrum'da Yeme-içme Tesislerinde Menülerinde Mandalinalı Ürünlerin Varlığı:}

Katılımciların tamamı Bodrum Narenciye Üreticileri Birliği'nce üretilen mandalina gazozunun dahi pek çok yeme-içme tesisinde bulunmadığını, özellikle üst düzey gelir gruplarına hitap eden zincir otellerde müşterilere sunulmadığını, Belediye tarafindan işletilen yemeiçme tesislerinde mandalina gazozunun servis edildiğini, zaman zaman da mandalinalı dondurmaların satışa sunulduğunu, ancak bunların yeterli olmadığını dile getirmişlerdir. Katılımcılar, öncelikle yerelde mandalinalı ürünlerin kullanımının yaygınlaştırılması gerektiğini ifade etmişlerdir.

Katılımcı 3: "Malum gazozdan başka bir ürünün satıldığını görmedim. Şefler yaratıcı reçeteler ve menüler oluşturmalı."

Katılımcı 20: "Mandalina şenliklerinde menülere mandalinalı lezzetlerin dahil edilmesi yönünde görüşmelerimiz oldu ama değişen pek bir şey olmadi."

Katılımcı 21: "Mandalinanın suyundan başka bir şey satılmıyor. Çok yazık." diyerek konuya gereken önemin verilmediğini vurgulamışlardır.

\section{Bodrum Mandalinası Bahçelerinin Turizme Açılmasının Kırsal Kalkınmaya Etkisi:}

Katılımcıların yaklaşık \%95'i Bodrum mandalinası bahçelerinde tarım turizmi uygulamalarının desteklenmesi gerektiğini, bunun sürdürülebilir kalkınmayı olumlu etkileyeceğini, gelecek kuşakların coğrafi işaret tescili bulunan bu tarımsal ürünü çok daha yüksek katma değerli ürünlere dönüştürebileceğini dile getirmişlerdir. Özellikle Dereköy, Bitez, Ortakent ve Gümüşlükte yer alan bahçelerin turistlerin çok kısa bir zaman sürecinde deniz-kum-güneş turizminin yanı sıra doğayla iç içe yaşayabileceği ve tarımsal faaliyetleri deneyimleyebileceği eşsiz bir eko-sisteme sahip olduğunu ifade etmişlerdir. $\mathrm{Bu}$ tür turizm faaliyetlerinin çevrenin korunmasını olumlu etkileyeceğini, kültürlerarası diyaloğun 
gelişeceğini, karşılıklı bilgi alışverişi için ortam hazırlanacağını, turistlerin sorumlu tüketim alışkanlıkları edinmelerine yol açacağını, yöre halkının sahip olunan değerlerin kıymetinin bilineceğini belirtmişlerdir. Katılımcıların \%5'i halkın alışkanlıklarından kolay kolay vazgeçemeyeceğini ve gençlerin tarıma ilgisizliği sebebiyle gelecekte bahçelerin zamanla tamamen yok olacağını, öngörmüşler ve Bodrum mandalinası bahçelerinin turizme açılmasının kırsal kalkınma üzerindeki etkisinin konuşulmasının çok da anlamlı olmadığını ifade etmişlerdir.

Katılımcı 4: "Biz eşimle gece gündüz çalışıyoruz. Çocuklarımız başka yerlerde çalışıyor. Bizden sonra ne olur bilinmez. Keşke bu konuda zamanında önlem alınsaydı. Ailecek bir arada olur, geçim derdimiz olmazdı. Arazilerimiz çok verimli, yıl içinde 3-4 kez ürün alıyoruz. Yoldan geçen turistler bahçelerimize imreniyor. Ağaçlardan mandalina toplamaya bayıliyorlar. Biraz sermayemiz olsa konuk ağırlayabileceğimiz 1-2 oda hazırlayabiliriz." derken,

Katılımc 19: "Yıllardır hem tarım hem turizmle ilgileniyorum, bahçelerime gözüm gibi bakıyorum. Bugünlere bu bahçeler sayesinde geldik." diyerek konuyu özetlemiştir.

\section{Bodrum Mandalinası Bahçelerinin Turizme Açılmasının Olumsuz Etkileri:}

Katılımciların tamamı Bodrum Mandalinası bahçelerinin turizme açılmasının herhangi bir olumsuz etkiye yol açmayacağını, tersine ekolojik dengenin korunmasına yol açacağı için turizmin sürdürülebilirliğine azami katkı sağlayacağı konusunda fikir birliğine varmışlardır.

\section{Tarım Turizmi Kapsamında Bodrum Mandalinası Bahçelerine Yapılacak Yatırımlarda Çevresel Sürdürülebilirliğin Temini, Yenilenebilir Enerji Kaynaklarının Kullanılması:}

Katılımcıların tamamına yakını, Muğla Çevre Platformunun çalışmalarını takip etmekte, sadece tarım turizmi amaçlı değil ilçeye yapılacak her yatırımda çevresel sürdürülebilirliğe ve yenilenebilir enerji kaynaklarının kullanılmasının zorunluluk olduğunu dile getirmektedir. Katılımcıların tamamı Bodrum'un güneş enerjisi açısından çok yüksek bir potansiyele sahip olduğunu, bugüne kadar yüksek maliyetler nedeni ile güneş enerjisine dayalı yatırımların yapılamadığını, tarımsal üretimde yenilenebilir enerji kaynaklarının mutlaka kullanılması gerektiğini, tarımsal ürünlerin muhafazasında ve yeni ürün üretiminde yenilenebilir enerji kaynaklarının kullanılmasının önemli olduğunu vurgulamışlardır.

Katılımcı 5: "Oğlum bu işlere meraklı. Eşim bahçemize güneş paneli koydu. Depremde elektriksiz kalmadık. $\mathrm{Bu}$ panelle bahçemizin sulanması için uğraşıyor. Elektrik pahalı. Her şeyi tüketiyoruz. Üretmek lazım. Buralarda güneş bol, yeterince değerlendiremiyoruz."

Katılımcı 7: "Görevim icabı çiftçileri ziyaret ediyoruz. Bu konuda destekler artarsa tarımda temiz enerjinin kullanılması yaygınlaşır."

Katılımcı 19: "Elektrik giderlerimiz çok yüksek. Sicak suyu güneş enerjisi ile sağliyoruz ama klimalar için farklı sistemler geliştirilmeli. Ayrıca yıllardır toplanan narenciyenin saklanması için yapılacak soğuk hava deposunda güneş enerjisi kullanalım, mandalinaları güneş enerjisi ile kurutalım diye konuşuyoruz ama bir proje geliştiremedik." diyerek sahip olunan bu enerji kaynağının değerlendirilmesi gerektiğine dikkat çekmişlerdir.

\section{Bodrum Mandalinası Bahçelerinin Sürdürülebilir Turizm Kapsamında Kullanılması:}

Bodrum Mandalinası üreten katılımcılar (yaklaşık $\% 60)$ tarımsal üretimde girdi maliyetlerinin, elde edilen gelirin zaman zaman üzerine çıkabildiğini, bu nedenle çoğu bahçenin kaderine terk edildiğini belirtmektedir. $\mathrm{Bu}$ farkındalık, üretici olmayan diğer katılımcılarda da mevcuttur. Katılımcıların tamamı mandalina bahçelerinin turizme açılmasını, çoğu bahçede bulunan ve atıl ya da yıkık durumda bulunan taş evlerin, kuyuların değerlendirilerek bahçe sahiplerine ek gelir sağlayacağını, bahçelerin korunarak kullanımının yaygınlaştırılması gerektiğini, karar alıcıların bu konuda yöre halkını desteklemesi gerektiğini dile getirmiştir. Bazı katılımcıların bu konuda görüşü şu şekildedir:

Katılımc1 3: "Olumlu! Şu bir gerçek ki, bahçe sahiplerinin bahçedeki ürünleri satarak elde ettikleri kazanç bahçe bakımı için yaptıkları harcamalardan daha az, bu nedenle turizm ek bir gelir sağlayabilir ve bahçe sahiplerinin bahçelerini satmalarının önüne geçilebilir." 
Katılımcı 20: "Yerelde üretmeli, yerelde tüketilmeli. Bodrum halkı mandalina bahçelerinin kıymetini bilmeli. Turist ağırlayabilecek odaları yoksa bahçelerinde kahvaltılar, muhtelif etkinlikler düzenleyebilirler."

\section{SONUC ve ÖNERILER}

Birleşmiş Milletler Dünya Turizm Örgütü, 2017 yılını Sürdürülebilir Turizm Yılı ilan etmiş ve bireylerin kaynakların gelecek kuşakların emaneti olduğunu unutmadan tüketmeleri gerektiği yönünde politikaların gelişmesine katkıda bulunmuştur. Dünyada ve ülkemizde kitle turizmine alternatif olarak insanların sakin, yalın, doğayla dost tatil yapabilecekleri turizm anlayışı gelişmektedir. Bunun için doğanın koruma ve kullanma dengesi gözetilmeli, böylelikle turizmin sürdürülebilirliği de sağlanmalıdır.

Deniz kum güneş ve eğlence turizminin öncü destinasyonlarından Bodrum'un, giderek kırsal yapısından uzaklaşarak kentleşmesiyle öne çıkmakla birlikte harika bir ekosisteme sahip bu ilçenin alternatif turizm türlerine müsait bir yapısı vardır. Mevcut durumun bu şekliyle kalması halinde tarım turizmine yönelik yapılabilecek aktiviteler mevcuttur. Akçay Özkan ve Yalçıner Ercoşkun (2019)'un yaptıkları çalışmanın sonucunda Doğa ile iç içe olma, doğal besinlerle beslenme, stresten, gürültüden, çevre kirliliğinden uzaklaşma gibi pek çok neden insanları kırsal alanlarda zaman geçirmeye yönlendirmektedir. Çiftlikler genel olarak doğayla buluşmayı, tanışmayı ve kaynaşmayı isteyen insanlarla birlikte kalabalıktan kaçmak ve sakin tatil yapmak isteyenler tarafindan tercih edilmektedir. Ayrica bu çiftliklere gelen ziyaretçiler kentlerin doğal ve kültürel yerlerine günübirlik geziler yapabilmekte ve kenti tanıma imkanı yakalayabilmektedir. $\mathrm{Bu}$ doğrultuda ekolojik çiftliklerde tatil yapma ve zaman geçirme isteği olan ziyaretçilerin doğal ve kırsal alanlarda zaman geçirdikçe çevre duyarlı davranışlarının arttığı ve kaynak koruma konusunda daha bilinçli hale geldikleri görülmektedir.

Özsezgin ve Ünlüönen (2018)'in yaptıklar1 'Destinasyon İmajının Markalaşmaya Etkisi: Bodrum Örneği' adlı çalışmada, Ziyaretçilerin Bodrum "u simgeleyen unsurlara ilişkin verdikleri cevaplara bakıldığında; \% 55,6 $6^{\mathrm{ec}} 1 \mathrm{k}$ oranla Bodrum

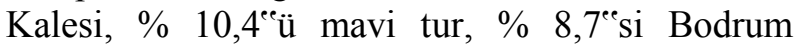
evleri, \% 8,4"ëu Barlar Sokağ1, \% 5,2eesi Antik
Tiyatro, \% 3,5ei Bodrum mandalinas1 \% 2,2eesi

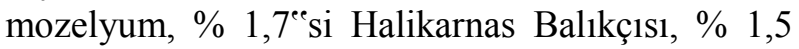
Suatlı Arkeoloji Müzesi, \% 1,2eesi amfora, \% 0,7 $7^{\text {ee }}$ si begonviller, $\% \quad 0,7^{\text {ee }}$ si süngercilik şeklinde bir sıralama ortaya çıkmıştır. Destinasyon imajı olarak kullanılabilecek gastronomik tek bir ürün olarak Bodrum mandalinasına yer verilmiş olması, Bodrum mandalinasının yiyecek-içecek odaklı tanıtımlarda ana ürün olarak algılanmasına yol açmıştır. Bodrum'daki konaklama işletmelerinde, Milas-Bodrum Havalimanı vb. belirlenecek olan yerlerde Bodrum mandalinalı lokum ikramı, Bodrum mandalinalı oda parfümlerinin kullanılmasının, yine aynı şekilde Bodrum'a/Bodrum'dan sefer düzenleyen otobüs firmalarına, havayolu şirketlerine Bodrum mandalinasından üretilen ürünlerin kullanılmasına teşvikler ya da zorunluluklar getirilmelidir.

Gastronomik unsurların agro-turizm çiftliklerindeki süreçlerinin incelendiği bir araştırmada (Deniz vd., 2018) ziyaretçilerin ürün toplama, hazırlama, pişirme, servis ve üretim aşamalarına ilgi gösterdikleri tespit edilmiştir. İlgili süreçlere katılımın ziyaretçi üzerinde kültürel etkileşim ve değişim yarattığ 1 belirlenmiştir. Yapılan mülakattaki cevaplara bakıldığında, turistlerin mandalina ağaçlarına ve ağaçlardan mandalina toplamaya ilgi gösterdiğini bununla birlikte TaTuTa çiftliğine ya da tarım turizmini ve bölge mimarisini destekleyen konaklama ve yemeiçme tesislerinin mandalina bahçelerine entegre edilmesi gerektiğinden bahsedilmiştir. Böylelikle gelen turistlerin, ağaçlardan mandalina toplama, yöre kültürüne özgü yiyecek ve içeceklerini hazırlama, toplanan mandalinalardan lokum, reçel vb. ürünlerin yapım atölyelerine katılma olanakları olacak ve mandalina bahçelerindeki konaklama imkânından yararlanabilecektir.

Araştırmada katılımcılar yaşanan her türlü olumsuzluğa rağmen, coğrafi işaret tescilli 'Bodrum Mandalinasının korunmasının gerektiğini ve bu konuda sayıları az da olsa azimli ve ümidini yitirmemiş üreticinin bulunduğunu, ürünün katma değeri arttıkça üretim alanlarının genişleyebileceğini, bunun gelecek kuşaklara karş1 önemli bir sorumluluk olduğunu düşünmektedir. Mandalina bahçelerinde bulunan yöresel mimari örneklerinden taş evlerin koruma altına alınması, kısa süreli konaklamada ya da kahvaltı vb. yeme içme faaliyetlerinde kullanılmasında yarar 
görülmektedir. Az sayıda olan üreticilerin kuruluşlarca projeyle desteklenerek Bodrum mandalinasından üretilen ürünlerin çeşitlendirilmesi, tanıtılması, pazarlanması gibi konularda çiftçilere destek verilmelisi sağlanmalıdır. Ayrıca Muğla, Bodrum tanıtım filmlerinde mandalina bahçelerine, Bodrum mandalinasından üretilen ürünlere yer verilerek mandalina bahçelerinin bir çekim merkezine dönüştürülmesi gerekmektedir.

Bodrum Mandalinasının sürdürülebilirliği, öncelikle bu endemik tarımsal ürünün kıymetinin bilinmesi, ürünün katma değerli ürünlere dönüşümü için bilimsel çalışmaların desteklenmesi, mandalina bahçelerinin uzun vadeli bir planlama ile korunmas1, koruma kullanma dengesi gözetilen bahçelerin turizme kazandırılması yoluyla sağlanabilecektir. Konunun ulusal ve bölgesel turizm stratejik planlamalarında ve uygulama programlarında yer almas1 gerekmektedir. Bodrum'un eğlence odaklı turizm destinasyonu olmasının yanı sıra, doğal, kültürel, tarımsal, gastronomik açıdan zengin bir turizm destinasyonu olarak ön plana çıkarılması yönünde çalışmalara özel önem verilmelidir.

Araştırma kapsamında mandalina bahçelerinin gelecek kuşaklarca sahip çıkılması için tarım, ticaret, turizm sektöründe faaliyet gösterenlerin, kamu ve yerel yönetimlerin işbirliği yapmaları gerekmektedir. Aksi takdirde mandalina bahçelerinin sürdürülebilirliği daha fazla tehlikeye düşecektir. Bahçe sahiplerinin çocukları ya da torunlarının, mandalinanın ekonomik getirisinin azlığından dolayı farklı iş kollarında çalıştığı belirtilmiştir. Bununla birlikte Bodrum, özellikle deniz-kum-güneş odaklı turistlerin tercih ettiği bir destinasyon olması ve mandalinanın ekonomik getirisinin neredeyse olmaması sebebiyle coğrafi işaretli gastronomik kültürel miras olan Bodrum mandalinasının yetiştirildiği bahçeler yok edilerek yerlerine konaklama işletmeleri ve yiyecek işletmelerinin kurulduğu görülmektedir. Az sayıda kalan mandalina bahçesinin değerlendirerek gelecek kuşaklara aktarılması ve katmadeğerinin arttırılması gerekmektedir. Mandalina bahçelerinin sahipleri ile yerel yönetim, kültür turizm müdürlüğü, kalkınma ajansları, sivil toplum kuruluşları ve sektör temsilcileri ortak akıl ile hareket ederek çalışmalarını gerçekleştirmelidirler. Bodrum'da turizm çeşitlerinin arttırılarak turizm sezonunun uzatılması ve turizm gelirinin arttırılması gibi olumlu sonuçlara yol açacaktır. İnan (2007)'ın tarım turizmi ile ilgili yaptığı çalışmasında, tarım turizminin özellikle köylerde yaşayanların ek gelir elde edebileceği aktivitelerden birisi olarak belirtmektedir. Ziyaretçilerin barınma, beslenme ve güvenlik sorunları burada üzerinde durulması gereken en önemli konulardır. Temel hijyen ve servis kuralları, turizm, pansiyonculuk konularında eğitim verilmesi oldukça önemlidir.

Bodrum'da düzenlenen, Bodrum Mandalina Festivali ve diğer etkinliklerde Bodrum mandalinasından geliştirilmiş olan ürünlerin katılımcılara sunularak yeni bir tursitik ürün yaratılmasina ve Bodrum mandalinasından hazırlanabilecek olan tatli, salata vb. yiyecek ve içeceklerin Bodrum'da faaliyet gösteren yiyecek içecek işletmelerinin menülerinde yer almasına yönelik çalışmalar yapılmalıdır. Bu ve bunun gibi yaklaşımların hem tanıtım hem de tutundurma faaliyetlerine katkı sunacağı düşünülmektedir. Şu anda etkin olarak kullanılan Bodrummandalini.com gibi web siteleri aracılığıyla satış-pazarlama ve tanıtımıyla, öncelikli olarak Bodrum Mandalinasının dünyaya tanitılarak bölgeye tarım turizmi talebinde olan turistlere çekici etki yaratması beklenmektedir.

Araştırmanın Bodrum mandalina bahçelerine ilişkin, Bodrum'da faaliyet gösteren sivil toplum kuruluşlarına yönelik olarak gerçekleştirilmiş olması, bu çalışmanın sınırlılığını oluşturmaktadır. İleriye yönelik yapılacak daha geniş kapsamlı ve katılımlı araştırmalar ile genellenebilir sonuçların elde edilmesi ve yorumlanması mümkün kılacaktır.

Araştırmada kullanılan mülakat soruları sivil toplum kuruluşu yönetici, üye ve gönüllülerine uygulanmıştır. Daha sonraki çalışmalarda bu mülakat soruları bahçe sahiplerinin ikinci, üçüncü kuşak üyelerine uygulanması bahçelerin sürdürülebilirliğinin temini açısından alınabilecek önlemleri yönlendirebilecektir.

\section{KAYNAKÇA}

Acar, Y. (2018). Türkiye'deki Coğrafi İşaretli Ürünlerin Destinasyon Markalaması Kapsamında Değerlendirilmesi. Journal of Tourism and Gastronomy Studies, 6(2), 163-177. 
Agritourism,

(2011). http://www.agritourism.in/about-agritourism.html. (Erişim Tarihi: 01.06.2018).

Ağaoğlu, D. (2018), Bodrum Mandalinasi Üreticilerinin Tarım Turizmi Farkındalıklarının Belirlenmesi ve Uygulama Önerisi, 7. Ulusal Kırsal Turizm Kongresi Bildiri Kitapçı̆̆ı, Muğla.

Ak, İ. (2006). Turizmde Yeni Seçenekler: EkoTurizm ve Tarım Turizmi, 3. Organik Tarım Sempozyumu, Atatürk Bahçe Kültürleri Merkez Araştırma Enstitüsü, 475-481, Yalova.

Akçay Özkan, B. \& Yalçıner Ercoşkun, Ö. (2019). İç Anadolu Bölgesi'ndeki Ekolojik Çiftliklerde Tarım Turizmi. Balkan ve Yakın Doğu Sosyal Bilimler Dergisi, 5(3), 78-89.

Akkaşoğlu, S., Akyol, C., Ulama, Ş., ve Zengin, B. (2019). Tarım Turizmine Yönelik Hazırlanan Lisansüstü Tezlerin Bibliyometrik Analizi. The Journal of Tourism and Gastronomy Studies, 7(2), 1193-1218.

Akova, S. B., \& Şahin, G. (2019). Turizmde Tarım Ürünlerinin Değerlendirilmesi: Muz Örneği. XI. International Balkan and Near Eastern Social Sciences Congress, Tekirdağ. 812-822.

Buğday Derneği, Tatuta Ekolojik Çiftliklerde Tarım Turizmi ve Gönüllü Bilgi, Tecrübe Takası, www.tatuta.org.

Civelek, M. (2013). Sürdürülebilirlik Kapsamında Agro-Turizm ve Kırsal Kalkınma İlişkisi: Muğla Yöresindeki Tatuta Çiftliklerinin Agro-Turizm Potansiyeli Yönünden Değerlendirilmesi. Yüksek Lisans Tezi, Muğla Sitkı Koçman Üniversitesi Sosyal Bilimler Enstitüsü Turizm İşletmeciliği Anabilim Dalı, Muğla.

Civelek, M., Dalgın, T. ve Çeken, H. (2014). AgroTurizm ve Kırsal Kalkınma İlişkisi: Muğla Yöresindeki Agro-Turizm Alanlarında Bir Araştırma, Turizm Akademik Dergisi, 1 (1), 15-28.

Çeken, H., Karadă̆, L. ve Dalgın, T. (2007). Kırsal Kalkınmada Yeni Bir Yaklaşım Kırsal Turizm ve Türkiye'ye Yönelik Teorik Bir Çalışma. Artvin Çoruh Üniversitesi Orman Fakültesi Dergisi

Daşdemir, İ., \& Yılmaz, A. (2016). Sürdürülebilir Kırsal Kalkınmada ORKÖY'ün Rolü (Samsun Orman İşletmesi Örneği). In 3rd International Symposium on Environment and Morality (ISEM2016) 4-6 Nov 2016. Alanya/AntalyaTurkey.
Deniz, S., Özden, O., Akgün, O. ve Yıldırım, M., H. (2018). Agro turizm tesislerinin gastronomi faaliyetleri açısından incelenmesi: Çanakkale örneği. Journal of Tourism and Gastronomy Studies. 6 (3), 364-378., 8(1), 1-14.

Dorobantu, M. R. and Fieldsend, A. (2011). Rural environment-a promoter of sustainable tourism within local communities in Romania". In 18th International Economic Conference-IECS. 47-52.

Esengün, K., Akça, H. ve Sayılı, M. (2000). Dağlık ve Ormanlık Alanlarda Kırsal Turizm Faaliyeti ve Sürdürülebilir Kırsal Kalkınma. I. Ulusal Ormancılık Kooperatifleri Sempozyumu, 150-158, Kastamonu.

Geray, U. (1998). Ulusal Çevre Eylem Planı. Orman Kaynakları Yönetimi. DPT yayını. Ankara.

Gülçubuk, B. (2002). Kırsal Kalkınma Politikaları. www.kirsalcevre.org.tr,

http://www.kirsalcevre.org.tr/foto/file/kirsal_kalki nma_politikalari_bulentg.pdf (erişim tarihi, 10.12.2017).

Gündüz, S. (2004). Ankara İli Kalecik İlçesindeki Tarımsal Turizme Uygun Alanların Saptanmast ve Tarımsal Turizm Modelinin Oluşturulması Üzerine Bir Araştırma. Doktora Tezi. Ankara Üniversitesi Fen Bilimleri Enstitüsü Peyzaj Mimarlığı Ana Bilim Dalı, Ankara.

Hodur, N. M., Leistritz, F. L., \& Wolfe, K. L. (2008). Developing the nature-based tourism sector in southwestern North Dakota. Great Plains Research, 81-92.

İnan Ç., 2007. Yıldız (Istranca) Dağları ve Çevresindeki Floradan Sürdürülebilir Kırsal Kalkınma ve Ekoturizm Amacryla Yararlanma Olanakları. Namık Kemal Üniversitesi Fen Bilimleri Enstitüsü, Tarım Ekonomisi Anabilim Dal1, s. 1-61.

Karakaya, A. G. (2017). Dalaman ve Fethiye yöresindeki hayvancılı işletmelerinin AgroTurizm potansiyeli. Yükseklisans Tezi. Adnan Menderes Üniversitesi, Fen Bilimleri Enstitüsü, Aydin.

Kosmaczewska, J. (2008). The Relationship Between Development of Agritourism in Poland and Local Community Potential, Studies in Physical Culture And Tourism, 2(15), 141-148.

Kilıç, B. ve Kurnaz, A. (2010). Alternatif turizm ve ürün çeşitliliği oluşturmada ekolojik çiftlikler: 
Pastoral Vadi örneği. Iş̧letme Araştırmalar Dergisi, 2(4), 39-56.

Küçükaltan, D. (2002). Tarım Turizmi ve Türkiye'de Tarım Turizmi İşletmeciliği. 2.Turizm Şurası Bildirisi.12-14 Nisan, 1: 143-159.

Kuşat, N. (2014). Sürdürülebilir Kırsal Kalkınma İçin Bir Alternatif Olarak Kursal Turizm ve Türkiye'de Uygulanabilirliği. Ekonomik ve Sosyal Araştırmalar Dergisi, 10(2), 65-87.

Mercan, Ş. O. ve Üzülmez, M. (2014). Coğrafi İşaretlerin Bölgesel Turizm Gelişimindeki Önemi: Çanakkale İli Örneği. Dokuz Eylül Üniversitesi İktisadi İdari Bilimler Fakültesi Dergisi, 29(2), 6794.

Muğla Gazetesi.

http://www.muglagazetesi.com.tr/narenciye-

uretimi-yuz-guldurdu.html. (Erişim Tarihi: 01.05.2020).

Ongun U., Gövdere B. Ve Çiçek U. (2016). Yeşilovanın Kırsal Turizm Potansiyelinin Swot Analizi İle Değerlendirilmesi. Süleyman Demirel Üniversitesi Vizyoner Dergisi, 7(16), 75-88.

Özsezgin, İ., \& Ünlüönen, K. (2018). Destinasyon imajının markalaşmaya etkisi: Bodrum örneği. Journal of Recreation and Tourism Research, 5(4), 45-62.

Soykan, F. (2006). Avrupa'da Kursal Turizme Bakış Kazanılan Deneyim. II. Balıkesir Ulusal Turizm Kongresi, 72-73, Balıkesir.

Soykan, F. (2000). "Kursal Turizm ve Avrupa'da Kazanılan Deneyim", Anatolia: Turizm Araştırmaları Dergisi, Yıl: II, Türkçe-EylülAralık, 21.

Ryan, S., DeBord, K., \& McClellan, K. (2006). Agritourism in Pennsylvania: An Industry Assessment. A report by California University of Pennsylvania.

Sznajder, M., Prezborska, L. and Scrimgeour, F. (2009). Agritourism, UK: AMA DataSet LTD.

Şekerli, S. (2018). Tarım turizmi (TaTuTa) Projesi kapsamında faaliyet gösteren ekolojik çiftliklerde bir araştırma: İzmir ili örneği. Yüksek Lisans Tezi, İzmir, İzmir Kâtip Çelebi Üniversitesi.
Şen, B. (2005). Küçükbahçe'nin kadınları, 'agro turizmci' oldu...(2010) http://www.milliyet.com.tr/2005/06/26/business/bu s05.html

Turan, K.(1975). Türk Tarım Toplumunu Sosyal Politika Açısından "Merkez Köyler”, Uygulama Olanakları, Ankara İktisadi ve Ticari İlimler Akademisi.

Türkben, C., Gül, F. ve Uzar, Y. (2012). Türkiye'de Bağcılığın Tarım Turizmi (AgroTurizm) İçinde Yeri ve Önemi, KMÜ Sosyal ve Ekonomik Araştırmalar Dergisi, 14 (23): 47-50.

Türkiye'de Gastronomi Turizmi Derneği, 2017. "Gastronomi Turistlerine Yönelik Araştırma" http://www.gastronomiturizmidernegi.com.tr/.

(Erişim Tarihi: 01.07.2018).

TÜRSAB, 2020. https://www.tursab.org.tr/istatistikler/turist-sayisive-turizm-geliri, (Erişim Tarihi: 01.05.2020).

UNWTO, 2020. https://www.unwto.org/worldtourism-barometer-n18-january-2020. (Erişim Tarihi: 01.05.2020).

Uzunpınar, A. (2008), Katılım Öncesi AB Kırsal Kalkınma Politikası ve Türkiye'de Uygulanacak IPARD Programı Kapsamında Proje Hazırlama, Değerlendirme ve Seçim Süreci, http://diabk.tarim.gov.tr.

Üzümcü, T. P., Çelik, A., \& Özkul, E. (2016). Sürdürülebilir Kırsal Kalkınma için Yavaş Şehir Anlayış1: Kandıra Örneği. International Journal of Social and Economic Sciences (IJSES) E-ISSN: 2667-4904, 6(2), 41-51.

WEF- World Economic Forum (Dünya Ekonomik Forumu) Seyahat ve Turizm Rekabet Endeksi. (2017). https://www.weforum.org/reports/thetravel-tourism-competitiveness-report-2017.

Williams, P., Paridaen, M., Dossa, K. and Dumais, M. (2001). Agritourism Marketand Product Development Status Report. Centre for Tourism Policy and Research, Simon Fraser University. Erişim Tarihi: $\quad 10.12 .2017$ http://www.rem.sfu.ca/pdf/ agritourism.pdf. 